\title{
Effects of the morphology and structure on the elastic behavior of (Ti,Si,Al)N nanocomposites
}

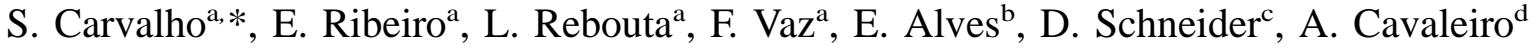 \\ ${ }^{a}$ Dept. Física, Universidade do Minho, Campus de Azurém, 4800-058 Guimaraes, Portugal \\ ${ }^{\mathrm{b}}$ ITN, Departamento de Física, E.N. 10, 2686-953 Sacavem, Portugal \\ ${ }^{\mathrm{c}}$ Fraunhofer Institute of Material Beam Technology, Winterbergstraße 28, 01277 Dresden, Germany \\ ${ }^{\mathrm{d}}$ ICMES - Fac. de Ciências e Tecnologia da Universidade de Coimbra, 3030 Coimbra, Portugal
}

\begin{abstract}
( Ti,Si,Al)N nanocomposite coatings with different $\mathrm{Ti}, \mathrm{Si}, \mathrm{Al}$ contents, were deposited onto silicon and polished high-speed steel substrates, by r.f. and/or d.c. reactive magnetron sputtering. The stoichiometry of the films was investigated by electron probe microanalysis and Rutherford backscattering spectrometry (RBS). The density was derived by combination of RBS results and thickness measurements obtained by ball-cratering. For comparison purposes, the evaluation of the Young's modulus was performed by depth-sensing indentation technique and with the laser-acoustic technique based on surface acoustic waves (SAW). Results showed in some cases differences in Young's modulus measured by both techniques. The Young's modulus obtained by SAW correlates with the density values from RBS, however, this behavior is not visible for the results measured with the ultramicroindentation technique. Both techniques indicate a small increase of Young's modulus of (Ti,Al)N by incorporating Si into the matrix. However, this improvement only occurs for small Si content, whereas for high Si content the elastic parameter reduces until almost $300 \mathrm{GPa}$. The morphology of the coatings was investigated by scanning electron microscopy and correlated with the differences observed by both SAW and indentation techniques.
\end{abstract}

(c) 2003 Elsevier Science B.V. All rights reserved.

Keywords: Ti-Si-Al-N; Nanocomposite; Young's modulus; SEM; Morphology; Porosity

\section{Introduction}

Surface hardening technologies are used to improve the fatigue and wear behavior of cutting tools. The hardening depth and the surface hardness are important parameters. However, the complexity of the mechanical behavior of coated materials requires understanding the relationship between microstructure, morphology and mechanical properties, since it is essential for improving the reliability and lifetime of coatings. An interesting parameter is the Young's modulus of the film. It is the main elastic constant of the material and can be measured non-destructively. High Young's modulus of the film usually goes with large stress in the coated material, which may give rise to microcracking and crack propagation. In the case of hard coatings, Young's modulus often correlates with hardness [1]. The Young's modulus is also influenced by several microstructural parameters,

\footnotetext{
*Corresponding author. Tel.: +351-253510470; fax: +351253510461.

E-mail address: nocas@fisica.uminho.pt (S. Carvalho).
}

such as the defects, density, [2], porosity [3], bonding condition within the material [4] and stoichiometry [5]. Therefore, the aim of this paper is to discuss and interpret Young's modulus results of $(\mathrm{Ti}, \mathrm{Si}, \mathrm{Al}) \mathrm{N}$ coatings as a function of microstructure and morphology, such as lattice parameters, texture, density and porosity. X-ray diffraction (XRD), scanning electron microscopy (SEM), Rutherford backscattering spectrometry (RBS) and electron probe microanalysis (EPMA) were used to study phase composition, morphology, chemical composition and density of the coated materials. In this paper Young's modulus will be determined by depth sensing microindentation and laser-acoustic (surface acoustic waves, SAW) techniques. Particular attention will be deserved to the effects of the morphology and structure on the differences observed by both techniques.

\section{Experimental details}

\subsection{Film preparation}

The four groups of coatings of $(\mathrm{Ti}, \mathrm{Si}, \mathrm{Al}) \mathrm{N}$ examined in this work were deposited by reactive magnetron 
Table 1

Some experimental parameters and properties relative to dc sputtered samples

\begin{tabular}{|c|c|c|c|c|c|c|c|c|c|c|}
\hline \multirow[t]{2}{*}{ Sample } & \multirow[t]{2}{*}{ Composition } & \multirow[t]{2}{*}{$\begin{array}{l}I_{\text {target }} \\
(\mathrm{A})\end{array}$} & \multirow[t]{2}{*}{$\begin{array}{l}I_{\mathrm{b}} \text { (coil) } \\
(\mathrm{A})\end{array}$} & \multirow[t]{2}{*}{$\begin{array}{l}\text { Magnetic field } \\
(\mathrm{mT})\end{array}$} & \multirow[t]{2}{*}{$\begin{array}{l}\text { Bias } \\
(\mathrm{V})\end{array}$} & \multicolumn{2}{|c|}{$\begin{array}{l}\text { Thickness } \\
(\mu \mathrm{m})\end{array}$} & \multirow{2}{*}{$\begin{array}{l}\text { Density } \\
\left(\mathrm{g} / \mathrm{cm}^{3}\right) \\
\text { RBS }\end{array}$} & \multicolumn{2}{|c|}{$\begin{array}{l}\text { Young's modulus } \\
(\mathrm{GPa})\end{array}$} \\
\hline & & & & & & $\mathrm{BC}$ & SEM & & SAW & IND \\
\hline TA5 & $\mathrm{Ti}_{0.45} \mathrm{Al}_{0.55} \mathrm{~N}$ & 1 & 0 & 3.3 & -50 & 3.7 & - & 3.7 & 279 & 480 \\
\hline XTSA1 & $\mathrm{Ti}_{0.64} \mathrm{Al}_{0.26} \mathrm{Si}_{0.09} \mathrm{~N}_{1.01}$ & 1 & 0 & 3.3 & -50 & 1.8 & - & 3.8 & 236 & 295 \\
\hline XTSA9 & $\mathrm{Ti}_{0.54} \mathrm{Al}_{0.28} \mathrm{Si}_{0.13} \mathrm{~N}_{1.05}$ & 1 & 3 & 7.1 & -70 & 2.2 & 2.3 & 4.2 & 327 & 406 \\
\hline XTSA13 & $\mathrm{Ti}_{0.60} \mathrm{Al}_{0.28} \mathrm{Si}_{0.08} \mathrm{~N}_{1.04}$ & 1 & 5 & 9.5 & -70 & 1.9 & - & 4.5 & 355 & 400 \\
\hline XTSA2 & $\mathrm{Ti}_{0.54} \mathrm{Al}_{0.30} \mathrm{Si}_{0.12} \mathrm{~N}_{1.04}$ & 2 & 0 & 3.3 & -50 & 2.6 & 2.9 & 3.5 & 254 & 446 \\
\hline XTSA11 & $\mathrm{Ti}_{0.47} \mathrm{Al}_{0.32} \mathrm{Si}_{0.15} \mathrm{~N}_{1.06}$ & 2 & 3 & 7.1 & -50 & 2.1 & 2.3 & 4.6 & 339 & 444 \\
\hline XTSA14 & $\mathrm{Ti}_{0.82} \mathrm{Al}_{0.21} \mathrm{Si}_{0.05} \mathrm{~N}_{0.92}$ & 2 & 5 & 9.5 & -70 & 2.5 & - & 4.5 & 299 & 491 \\
\hline
\end{tabular}

All the samples were produced with a $0.2-0.3 \mathrm{~mm}$ thick TiAl adhesion layer, with a $200{ }^{\circ} \mathrm{C}$ as substrate temperature.

sputtering in an $\mathrm{Ar} / \mathrm{N}_{2}$ atmosphere. One group of ( Ti,Si,Al)N coatings were deposited by d.c. reactive magnetron sputtering in a laboratorial deposition system that consists of two vertically opposed rectangular magnetrons in a closed field configuration [6] (Table 1). Two groups of (Ti,Si,Al)N samples was deposited by a combination of r.f. and d.c. reactive magnetron sputtering from high purity $\mathrm{Ti}, \mathrm{Si}$ and $\mathrm{Al}$ targets in an Alcatel SCM 650 system [7]. Some experiments were carried out with $\mathrm{Ti}$ and $\mathrm{Si}$ targets coupled to r.f. while $\mathrm{Al}$ target was coupled to the d.c. source (Tables 2 and 3). Some of these samples were produced with the $\mathrm{Ti}$ target coupled to a d.c. power supply (Table 3). The fourth group of samples (Table 3) was produced in static mode with pieces of $\mathrm{Si}$ and $\mathrm{Al}$ incrusted into the $\mathrm{Ti}$ target, which was coupled to the r.f. power supply. Further detailed information regarding the depositions process can be found elsewhere $[6,24,39]$.

\subsection{Characterization techniques}

The atomic composition of the as deposited samples was investigated by RBS and EPMA. RBS was performed using a $2 \mathrm{MeV} \mathrm{He}^{+}$beam and a $1.5 \mathrm{MeV} \mathrm{H}^{+}$ beam in order to obtain the areal atomic density (atoms/ $\mathrm{cm}^{2}$ ), of the films. An average number of five ballcratering (BC) experiments were performed in each sample in order to determine its thickness. The coatings were structurally characterized by XRD experiments undertaken in a Philips PW 1710 apparatus using a $\mathrm{Cu}$ $\mathrm{K} \alpha$ radiation. The cross-sectional morphology was examined using a conventional SEM on fractured samples. A computer-controlled Fischercope H100 ultramicrohardness tester, equipped with a Vickers diamond indenter was used in order to obtain the Young's modulus of coatings $[8,9]$. The Young's modulus was

Table 2

Properties relative to $\mathrm{rf}$ and dc sputtered samples

\begin{tabular}{|c|c|c|c|c|c|c|c|c|}
\hline \multirow[t]{2}{*}{ Sample } & \multirow[t]{2}{*}{ Composition } & \multirow[t]{2}{*}{ Substrate } & \multicolumn{2}{|c|}{ Thickness $(\mu \mathrm{m})$} & \multicolumn{2}{|c|}{ Density $\left(\mathrm{g} / \mathrm{cm}^{3}\right)$} & \multicolumn{2}{|c|}{$\begin{array}{l}\text { Young's modulus } \\
(\mathrm{GPa})\end{array}$} \\
\hline & & & $\mathrm{BC}$ & SEM & RBS & SAW & IND & SAW \\
\hline TSA82 & $\mathrm{Ti}_{0.65} \mathrm{Al}_{0.35} \mathrm{~N}$ & HSS & 1.5 & 1.4 & 5.1 & & 459 & 421 \\
\hline TSA88 & $\mathrm{Ti}_{0.62} \mathrm{Si}_{0.04} \mathrm{Al}_{0.34} \mathrm{~N}$ & HSS & 1 & - & - & & 466 & - \\
\hline TSA90 & $\mathrm{Ti}_{0.58} \mathrm{Si}_{0.07} \mathrm{Al}_{0.35} \mathrm{~N}$ & HSS & 1.8 & - & - & & 454 & - \\
\hline TSA83 & $\mathrm{Ti}_{0.50} \mathrm{Si}_{0.13} \mathrm{Al}_{0.37} \mathrm{~N}$ & $\begin{array}{l}\text { HSS } \\
\text { Silicon }\end{array}$ & 2.0 & - & 5.0 & 5.3 & $\begin{array}{l}496 \\
-\end{array}$ & $\begin{array}{l}466 \\
490\end{array}$ \\
\hline TSA89 & $\mathrm{Ti}_{0.55} \mathrm{Si}_{0.14} \mathrm{Al}_{0.31} \mathrm{~N}$ & HSS & 1.7 & - & - & - & 344 & - \\
\hline TSA84 & $\mathrm{Ti}_{0.54} \mathrm{Si}_{0.18} \mathrm{Al}_{0.28} \mathrm{~N}$ & $\begin{array}{l}\text { HSS } \\
\text { Silicon }\end{array}$ & 1.8 & 1.9 & 4.7 & $3.9^{*}$ & $\begin{array}{l}289 \\
-\end{array}$ & $\begin{array}{l}323 \\
252 *\end{array}$ \\
\hline TSA85 & $\mathrm{Ti}_{0.53} \mathrm{Si}_{0.23} \mathrm{Al}_{0.24} \mathrm{~N}$ & $\begin{array}{l}\text { HSS } \\
\text { Silicon }\end{array}$ & 1.9 & - & 4.3 & 4.4 & $\begin{array}{l}269 \\
-\end{array}$ & $\begin{array}{l}206 \\
288\end{array}$ \\
\hline TSA86 & $\mathrm{Ti}_{0.53} \mathrm{Si}_{0.24} \mathrm{Al}_{0.23} \mathrm{~N}$ & $\begin{array}{l}\text { HSS } \\
\text { Silicon }\end{array}$ & 2.0 & & 4.1 & 4.0 & $\begin{array}{l}284 \\
-\end{array}$ & $\begin{array}{l}300 \\
282\end{array}$ \\
\hline TSA87 & $\mathrm{Ti}_{0.41} \mathrm{Si}_{0.34} \mathrm{Al}_{0.25} \mathrm{~N}$ & $\begin{array}{l}\text { Steel } 310 \\
\text { Silicon }\end{array}$ & 2.9 & & 3.9 & 3.9 & $\begin{array}{l}293 \\
-\end{array}$ & $\begin{array}{l}235 \\
280\end{array}$ \\
\hline
\end{tabular}

All the samples were produced with a $0.35 \mathrm{~mm}$ thick Ti adhesion layer, with $-70 \mathrm{~V}$ as bias voltage and $400^{\circ} \mathrm{C}$ as substrate temperature.

*Bad adhesion. 
also measured by the laser-acoustic method, based on dispersion on SAW $[10,11]$.

\section{Results and discussion}

\subsection{Chemical analysis and density}

Tables 1-3 present the atomic composition (RBS and EPMA), the thickness (BC and SEM) and the density of the as-deposited samples. The density of the coatings was estimated from the ratio between the areal atomic density, extracted from RBS measurements, and the thickness. For high bandwidth of the measurement (40 $\mathrm{MHz}<f<160 \mathrm{MHz}$ ), the SAW test technique enables also to determine the density of the film in addition to Young's modulus. A good correlation between both techniques (RBS and SAW) was found.

\subsection{Young's modulus vs. Si content}

The results for the $(\mathrm{Ti}, \mathrm{Si}, \mathrm{Al}) \mathrm{N}$ films deposited by a combination of d.c. and r.f. reactive magnetron sputtering with the same bias voltage $(50 \mathrm{~V})$, temperature $(400$ $\left.{ }^{\circ} \mathrm{C}\right)$ but with different $(\mathrm{Ti}+\mathrm{Al}) / \mathrm{Si}$ target power and current combinations are present on Table 2. The films were deposited with $\mathrm{Si}$ contents in the range 0-17 at.\%. The influence of Si content on the Young's modulus obtained by ultramicroindentation and SAW is shown in Fig. 1. Both techniques indicate Young's modulus of (Ti,Al)N increasing with $\mathrm{Si}$ in the range of low amount of Si content, whereas for higher Si content a decreasing modulus is observed. As known from classical metallurgy, hindering the dislocation movement by lattice distortions increases the hardness of a material. In fact, the incorporation of a smaller silicon atom (Fig. 3a) into the lattice of TiAlN [12,13] (solid-solution hardening)

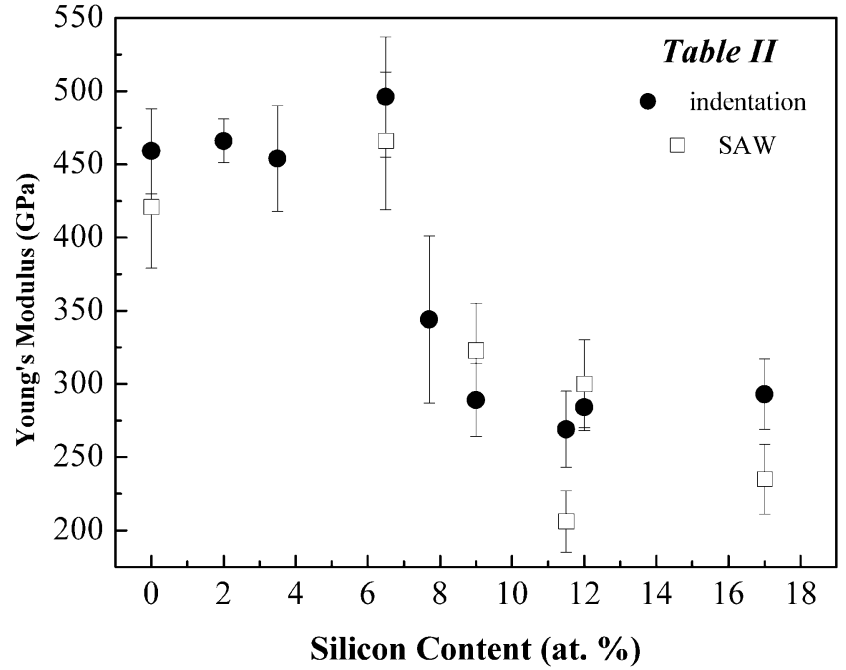

Fig. 1. Evolution of the Young's modulus determined by SAW and by ultramicroindentation as a function of the Si content, for the samples presented on Table 2 .

leads to a local tensile stress (lattice distortion), which contributes to the higher hardness [14-16]. These results suggest that for high Young's modulus the materials need higher external loading to move the dislocations that may be so high that micro-defects already develop on lower levels of load at micro-structurally preferred positions, causing the material to fail in a brittle manner, before the yield stress is reached. For higher Si contents the probable segregation of the $\mathrm{Si}$ atoms leads to the formation of an amorphous matrix of $\mathrm{Si}_{3} \mathrm{~N}_{4}$ [17-19]. The Young's modulus becomes quite similar to that of $\mathrm{Si}_{3} \mathrm{~N}_{4}(\sim 300 \mathrm{GPa})$ [20], being consistent with the increase of the referred amorphous matrix. This behavior could be also related with amorphous structure [21-23].

Table 3

Some experimental parameters and properties relative to $\mathrm{rf}$ and $\mathrm{dc}$ sputtered samples

\begin{tabular}{|c|c|c|c|c|c|c|c|c|c|c|}
\hline \multirow[t]{2}{*}{ Sample } & \multirow[t]{2}{*}{ Composition } & \multirow[t]{2}{*}{ Substrate } & \multirow[t]{2}{*}{ Ti target } & \multirow[t]{2}{*}{$\begin{array}{l}\text { Bias } \\
\text { (V) }\end{array}$} & \multicolumn{2}{|c|}{$\begin{array}{l}\text { Thickness } \\
(\mu \mathrm{m})\end{array}$} & \multicolumn{2}{|c|}{$\begin{array}{l}\text { Density } \\
\left(\mathrm{g} / \mathrm{cm}^{3}\right)\end{array}$} & \multicolumn{2}{|c|}{$\begin{array}{l}\text { Young's modulus } \\
\text { (GPa) }\end{array}$} \\
\hline & & & & & $\mathrm{BC}$ & SEM & RBS & SAW & SAW & IND \\
\hline TSA62 & $\mathrm{Ti}_{0.53} \mathrm{Al}_{0.25} \mathrm{Si}_{0.22} \mathrm{~N}$ & $\begin{array}{l}\text { HSS } \\
\text { Silicon }\end{array}$ & $\mathrm{rf}$ & -50 & 2.0 & 2.1 & 4.6 & - & 350 & 475 \\
\hline TSA63 & $\mathrm{Ti}_{0.55} \mathrm{Al}_{0.23} \mathrm{Si}_{0.22} \mathrm{~N}$ & $\begin{array}{l}\text { HSS } \\
\text { Silicon }\end{array}$ & $\mathrm{rf}$ & -70 & 1.7 & $\begin{array}{l}1.9 \\
1.9\end{array}$ & 4.3 & - & 293 & 431 \\
\hline TSA64 & $\mathrm{Ti}_{0.57} \mathrm{Al}_{0.24} \mathrm{Si}_{0.19} \mathrm{~N}$ & $\begin{array}{l}\text { HSS } \\
\text { Silicon }\end{array}$ & $\mathrm{dc}$ & -70 & 3.4 & 3.6 & 4.0 & $\overline{4} .0$ & 238 & 372 \\
\hline TSA67 & $\mathrm{Ti}_{0.60} \mathrm{Al}_{0.24} \mathrm{Si}_{0.16} \mathrm{~N}$ & $\begin{array}{l}\text { HSS } \\
\text { Silicon }\end{array}$ & $\mathrm{dc}$ & -100 & 2.6 & 2.8 & 4.5 & $\overline{4.4}$ & 321 & 504 \\
\hline TSA5* & $\mathrm{Ti}_{0.62} \mathrm{Al}_{0.18} \mathrm{Si}_{0.20} \mathrm{~N}$ & Silicon & rf - static & -50 & 2.2 & - & 4.4 & - & 289 & 310 \\
\hline TSA6* & $\mathrm{Ti}_{0.56} \mathrm{Al}_{0.18} \mathrm{Si}_{0.26} \mathrm{~N}$ & Silicon & $\mathrm{rf}-$ static & -50 & 3.3 & - & 4.3 & - & 332 & 322 \\
\hline TSA18 & $\mathrm{Ti}_{0.74} \mathrm{Al}_{0.18} \mathrm{Si}_{0.04} \mathrm{~N}_{0.98}$ & HSS & $\mathrm{Rf}$ & -50 & 1.3 & - & 4.0 & - & 374 & 382 \\
\hline TSA19 & $\mathrm{Ti}_{0.69} \mathrm{Al}_{0.17} \mathrm{Si}_{0.16} \mathrm{~N}_{0.98}$ & HSS & $\mathrm{Rf}$ & -50 & 1.3 & - & 3.8 & - & 368 & 289 \\
\hline
\end{tabular}

Some samples were produced with a $0.35 \mathrm{~mm}$ thick Ti adhesion layer.

*Without interlayer. 


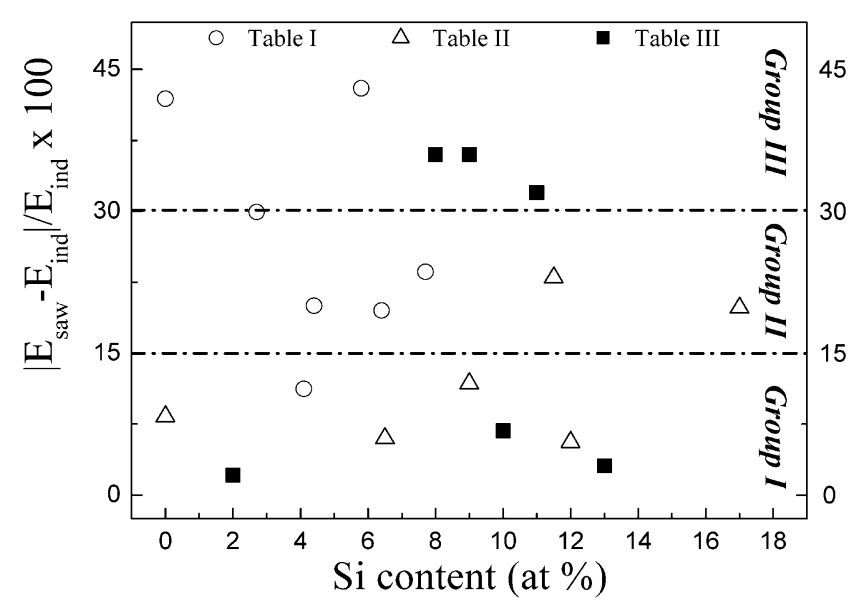

Fig. 2. Relative percentile difference between the Young's modulus evaluated by SAW and indentation techniques as function of Si content for all the $(\mathrm{Ti}, \mathrm{Si}, \mathrm{Al}) \mathrm{N}$ samples.

However, this discussion will be analyzed in a future work.

\subsection{Correlation between the indentation and the laser- acoustic results}

Concerning the samples presented on Table 2, the Young's modulus obtained by both techniques showed a good agreement. However, this is not true for all samples. In order to understand these differences, one will discuss the effect of several factors in the results: silicon content, structure, texture, density and morphology.

\subsubsection{Silicon content effect}

The relative percentile difference, $\left(\Delta E=\left(E_{\mathrm{SAw}}-\right.\right.$ $\left.\left.E_{\mathrm{IND}}\right) / E_{\mathrm{IND}}\right) \times 100$ ), between the Young's modulus evaluated by both techniques as function of $\mathrm{Si}$ content in the samples can be seen in Fig. 2. For a better comparative evaluation, the data in this figure are divided in three groups: group I for a $\Delta E<15 \%$, group II for a $15 \%<\Delta E<30 \%$ and group III for $\Delta E>30 \%$. As it is obvious from the analysis of this figure it does not seem there being any particular influence of the Si content on the discrepancy between the $E$ values determined by both techniques. For a particular value of at.\% Si (e.g. $\approx 6$ at. $\%$ ) the percentile difference can be very low $(7 \%)$ or very high (almost $45 \%$ ).

\subsubsection{Structure effect}

For sputtered hard coatings, the diffraction peaks are often quite broad due to either small grain sizes or high concentration of defects [24,25]. As it was already discussed in previous works [6,26,27], the diffraction peaks detected by XRD revealed the development of a multiphase system, depending on the deposition conditions: (i) a cubic phase with lattice parameter of approximately $4.20 \AA$ (e.g. TSA83 sample-see Fig. 3a) that corresponds to a solid solution ( $\mathrm{Ti}-\mathrm{Si}-\mathrm{Al}-\mathrm{N})$ where $\mathrm{Si}$ and $\mathrm{Al}$ atoms occupy $\mathrm{Ti}$ positions on the fcc TiN lattice; (ii) segregation of TiAlN nanocrystals in an amorphous $\mathrm{Si}_{3} \mathrm{~N}_{4}$ matrix leading to the formation of a nanocomposite film of nc-TiAlN $/ \mathrm{a}-\mathrm{Si}_{3} \mathrm{~N}_{4}$ type (e.g. TSA84 sample-see Fig. 3b); (iii) a mixture of the solid solution (Ti-Si-Al-N) and nc-TiAlN $/ \mathrm{a}-\mathrm{Si}_{3} \mathrm{~N}_{4}$ (e.g. TSA18see Fig. 3c); Moreover, the analysis of Fig. 3d (TSA86) allows to conclude that the film with 12 at.\% of $\mathrm{Si}$ content does not present signs of crystallization. Similar behavior was also found for $\mathrm{W}-\mathrm{Si}-\mathrm{N}$ coatings [23]. This result suggests that $\mathrm{Si}$ can induce amorphism; however, the threshold limit for this occurrence should be investigated in more detail.

The XRD results show that the structure is not a preponderant factor for good or bad agreement between

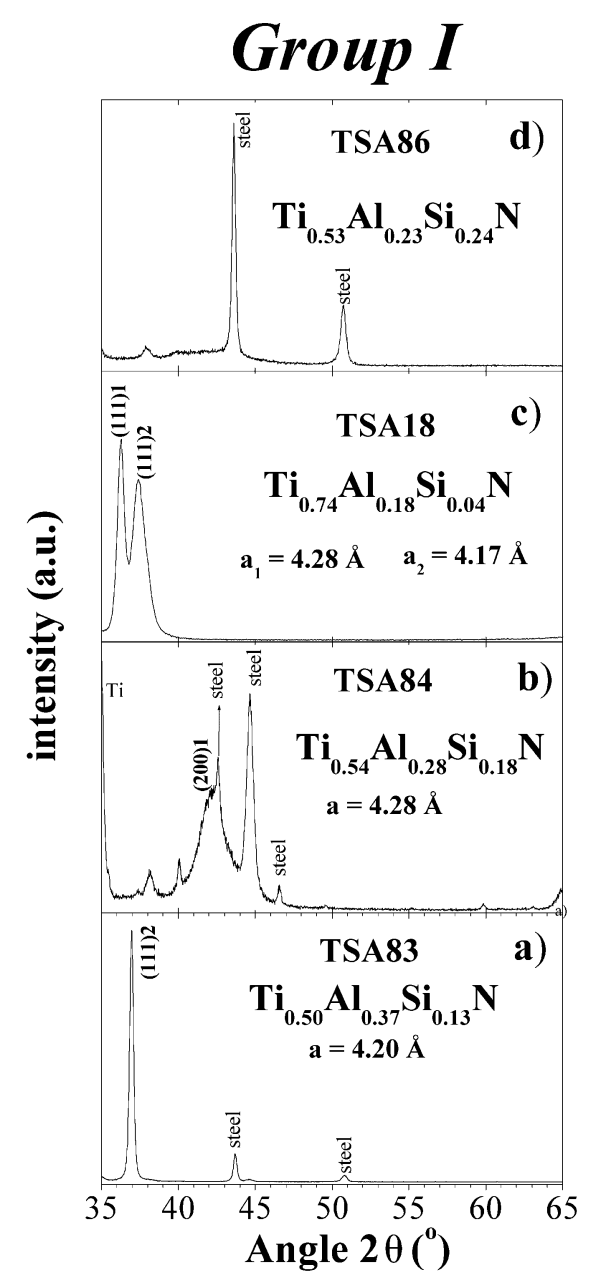

Fig. 3. Examples of XRD patterns illustrating examples of (Ti,Si,Al)N films with different structure but where the Young's modulus results obtained by both techniques are very similar: (a) solid solution-Ti$\mathrm{Si}-\mathrm{Al}-\mathrm{N}$; (b) a nanocomposite type nc-TiAlN $/ \mathrm{a}-\mathrm{Si}_{3} \mathrm{~N}_{4}$; (c) a mixture of phases; (d) amorphous structure. 


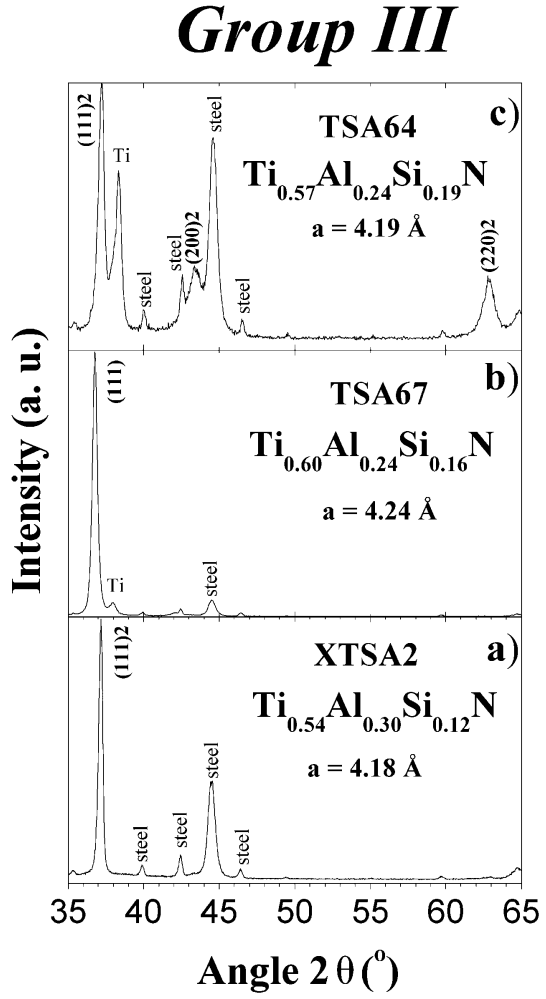

Fig. 4. Examples of XRD patterns illustrating examples of (Ti,Si,Al)N films with different preferential grow (texture) but where the Young's modulus results obtained by both techniques are very similar.

the results obtained by the indentation and the laseracoustic techniques. In fact, all the samples shown in Fig. 3 (TSA83, TSA84, TSA86 and TSA18) have different structure and belong to the same group $(\Delta E<$ $15 \%)$. Similar behavior is also visible for samples of group III (e.g. Fig. 4b and c).

\subsubsection{Texture effect}

Fig. 4 shows the XRD patterns for samples that belong to group III. Regarding the samples XTSA2 (Fig. 4a) and TSA64 (Fig. 4c), both indicate the so-called solid solution ( $\mathrm{Ti}-\mathrm{Si}-\mathrm{Al}-\mathrm{N})$. The XTSA2 sample displays a strong preferred ( 11111$)$ orientation parallel to the substrate surface. According to the XRD measurements for TSA64 sample, randomly oriented crystallites

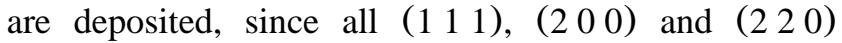
patterns are visible. Thus, XTSA2 is highly textured inversely to the TSA64 for which no significant preferential orientation is detected, and both samples belong to the group III (where the Young's modulus results obtained by both techniques are very different).

One can say that structure and texture are not responsible for the different values of Young's moduli measured with SAW and indentation.

\subsubsection{Morphology effect}

The morphology of the coatings is disclosed by crosssectional SEM micrographs of fractured samples in Figs. 5-7. Considering the results for samples representing the group I (Fig. 5), all films show dense and very compact featureless morphologies. With increasing silicon content the films become more and more compact (Fig. 5d-TSA86) resulting for high $\mathrm{Si}$ content in a glass-like morphology. Similar dependence of the morphology is also found for the nc-TiN/a- $\mathrm{Si}_{3} \mathrm{~N}_{4}$ [28]. The microstructure of single-phase films is qualitatively well described by structural zone models developed by Movchan and Demchishin [29] and Thornton [30]. These models, however, strongly change when impurities or selected additives are incorporated in the films [31,32]. Impurities or additives stop the grain growth and stimulate a renucleation of grains, which results in a globular morphology. XTSA11 (Fig. 6a) and TSA62 (Fig. 6b) samples present this type of morphology. The main feature of this structure is the presence of small grains since grain growth by coalescence is strongly restricted due to limited grain boundary mobility [33].

The coating representatives of group III (Fig. 7) have a columnar morphology, typical for coatings grown under low energetic ion bombardment and limited adatom mobility conditions. In fact these samples were prepared under such conditions as discussed in previous works $[6,34]$. The coatings are also very porous with a large number of voids within shaped crystallites. The voided growth defects that define the zone 1 of the Thornton's model are a consequence of atomic shadowing [30]. The discrepancies observed between the results obtained by both techniques can be related with microdefects density. Thus, it is possible to assume that the reduction in Young's modulus obtained by SAW is caused by pores, voids, defects and long-stretched-out zones with insufficient mutual bonding of adjacent material. Several papers about Young's modulus depending on porosity have already been published [35-39]. Basically, the effective Young's modulus depends on the elastic modulus of the bulk material, on the porosity and on the constants representing the effects of stress concentrations, which are determined by macroscopic structure of the materials investigated and their relaxation capacity. Kreher and Pompe [35] still admits another parameter depending on the pore shape that can be numerically calculated from the perturbation analysis of the elastic behavior of the solid for dilute dispersion of the pores [40]. A great number of studies about the influence of porosity on the Young's modulus are critically reviewed in Ref. [41], where mostly evaluation of sound velocity measurements were employed in order to obtain the elastic property. As an example, the data given for stoichiometric TiN varies from $79 \mathrm{GPa}[42,43]$ for a sample with porosity of $44 \%$ to $612 \mathrm{GPa}$ for a 

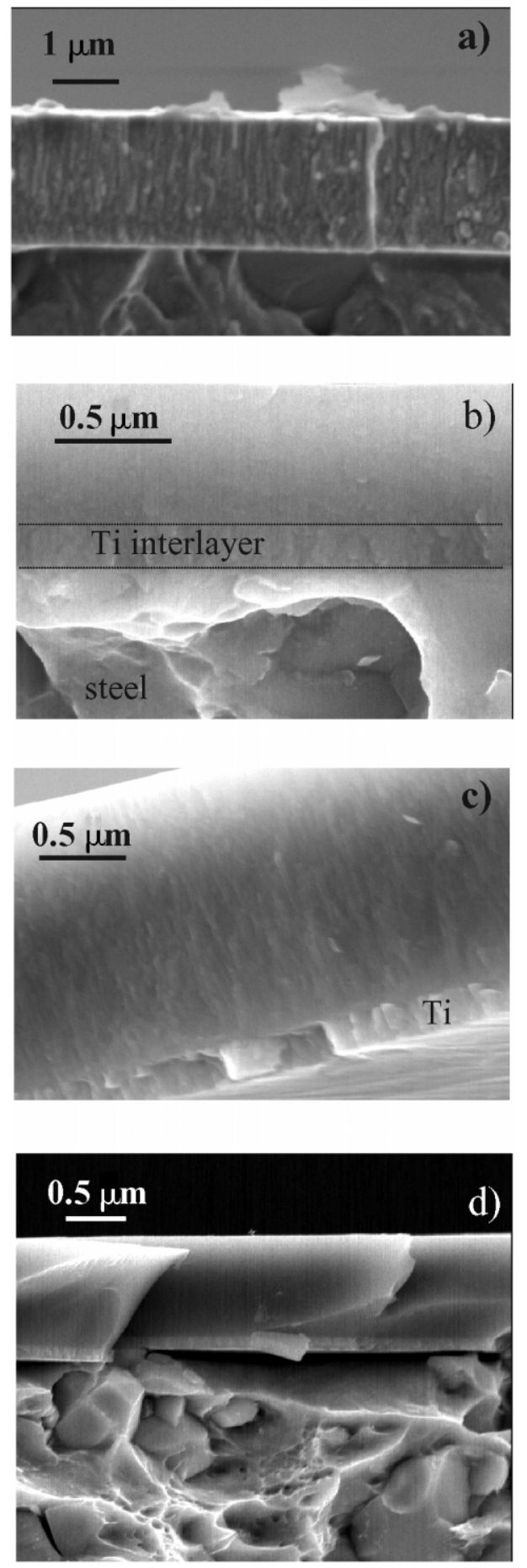

Fig. 5. Cross-section SEM images for samples representing the group $\mathrm{I}$, in which is visible a dense and a very compact featureless morphology.

bulk sample [44] and $640 \mathrm{GPa}$ for a film sample [45]. It can be concluded that the lower elastic moduli measured by SAW is the result of enhanced porosity in these films. The correlation between the results obtained by SAW and density is well understood, revealing an increase in Young's modulus with density.

The ultramicroindentation technique should not be so sensitive to the porosity. An exact indentation test needs a smooth and defect-free area. This suggests this technique to test more the matrix material instead the effective elastic material behavior. The indentation tester deforms the material much more than the SAW do. This can change the pore shape and compress the material beneath the indenter. The indentation test does not account for the inelastic deformation due to the propagation of cracks and pores to evaluate the elastic modulus values [46]. In this way, the effective elastic behavior approaches that of the bulk material. Both effects would explain that the indentation tester did not measure the effective elastic modulus of the films. However, for dense hard coatings, laser-acoustics and indention tester were shown to provide results with very good agreement [47].

\section{Conclusions}

In this paper, thin films within the $\mathrm{Ti}-\mathrm{Si}-\mathrm{Al}-\mathrm{N}$ ternary system were successfully deposited by PVD. Young's modulus was determined by depth sensing microindentation and laser-acoustic (SAW) techniques. Both techniques indicate that Young's modulus of (Ti,Al)N increase with Si content in the range of low amount of $\mathrm{Si}(<9$ at.\%) which can be due to a solution hardening. It seems that a high amount of $\mathrm{Si}$ content
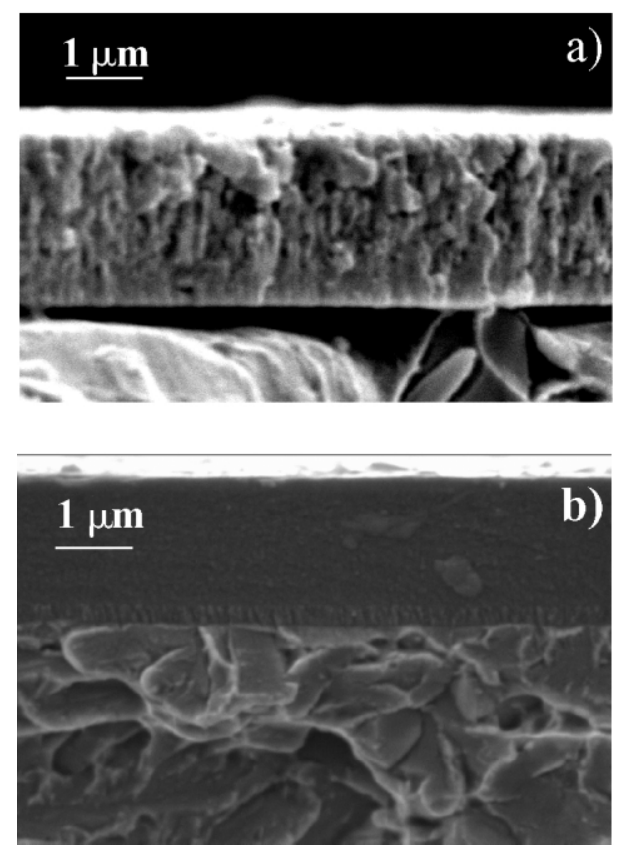

Fig. 6. SEM micrographs of the cross-section of ( $\mathrm{Ti}, \mathrm{Si}, \mathrm{Al}) \mathrm{N}$ films (group II) where is a visible granular morphology. 

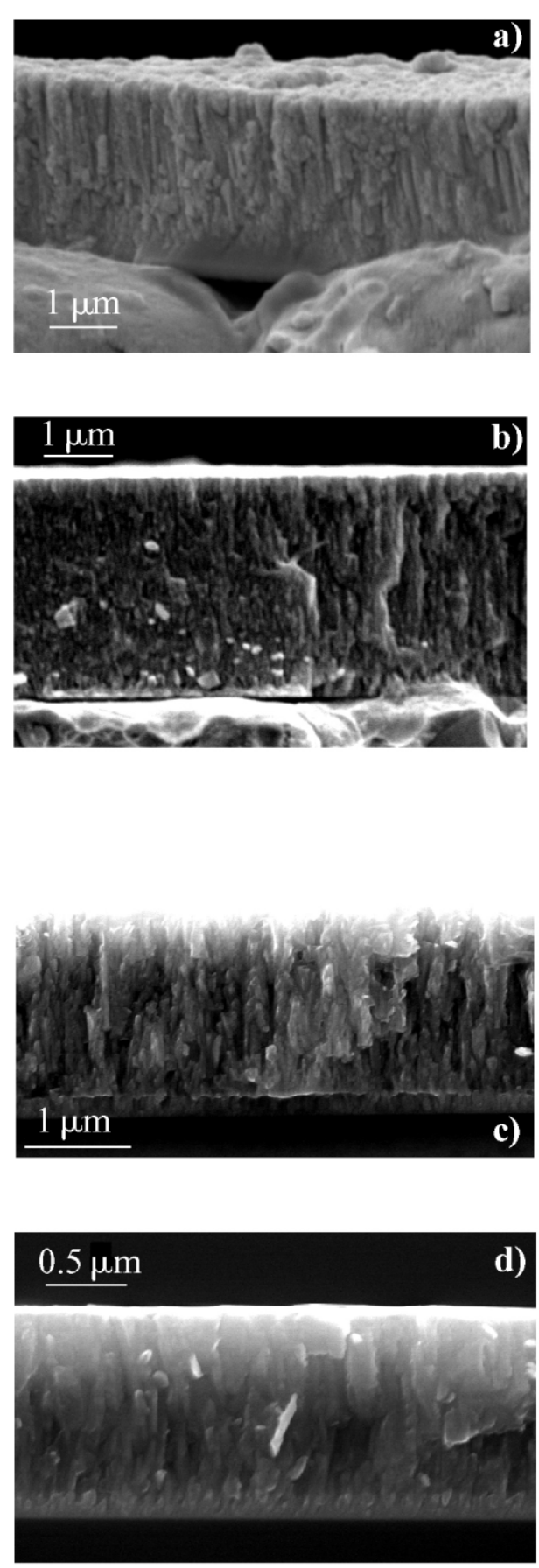

Fig. 7. Cross-sectional SEM micrograph of (Ti,Si,Al)N (group III) coatings displaying a columnar and a very porous structure.

induces the formation of amorphous phases and consequent a reduction on Young's modulus, also visible by both techniques. Coatings having a columnar structure and high porosity with a large number of voids within crystallites, show a large difference $(>20 \%)$ in elastic modulus obtained by the two techniques, being the laseracoustic values smaller. These low elastic moduli may be attributed to the effect of the defect structure in these coatings as shown in the micrographs obtained by SEM. When the films show dense and very compact morphologies (also visible on the cross-section SEM images) the results achieved by both techniques are very similar. Therefore the results support the former conclusions that the differences observed on the Young's modulus by both techniques are not related with the structure, neither with the texture but with the pore volume within the material. The results presented here suggest the possibility to make use of the differences between the results of both techniques for evaluating the defective structure of films that is of essential importance for the mechanical behavior.

\section{Acknowledgments}

The authors gratefully acknowledge the financial support of the 'Fundação para a Ciência e a Tecnologia' (FCT) institution by the project no. POCTI/32670/ CTM/2000 co-financed by European community fund FEDER, as well as the financial support of the German/ Portuguese DAAD/ICCTI institutions. S.C. also acknowledges a financial support from FCT (no. 4/5.3/ PRODEP/2000) during the course of this work.

\section{References}

[1] S. Veprěk, M. Haussmann, S. Reiprich, J. Vac. Sci. Technol. A 14 (1) (1996) 46.

[2] W. Pompe, H.A. Bahr, G. Gille, W. Kreher, B. Schultrich, H.J. Weiss, Mechanical properties of brittle materials, in: E. Kaldis (Ed.), Current Topics in Materials Science, vol. 12, North Holland, Amsterdam, 1985.

[3] R.M. Christensen, Mechanics of Composite Materials, Krieger Publishing Co, Malabar, 1991.

[4] X. Jiang, M. Reichelt, B. Strizker, J. Appl. Phys. 66 (1989) 5805.

[5] X. Jiang, M. Wang, K. Schmidt, J. Appl. Phys. 69 (1991) 3053.

[6] E. Ribeiro, A. Malczyk, S. Carvalho, et al., Surf. Coat. Technol. 152-152 (2002) 515.

[7] F. Vaz, L. Rebouta, S. Carvalho, L.A. Rocha, D. Soares, E. Alves, Mat. Sci. Forum 383 (2002) 151.

[8] J.M. Antunes, A. Cavaleiro, L.F. Menezes, M.I. Simões, J.V. Fernandes, Surf. Coat. Technol. 149 (2002) 27.

[9] M.I. Simões, J.V. Fernandes, A. Cavaleiro, Philos. Mag. A 82 (2002) 1911.

[10] D. Schneider, T. Schwarz, B. Schultrich, Experimentelle Technik der Physik 37 (1989) 307-318.

[11] D. Schneider, T. Schwarz, Surf. Coat. Technol. 91 (1997) 136-146.

[12] H.P. Klug, L.E. Alexander, X-ray Diffraction Procedures for Polycrystalline and Amorphous Materials, Wiley, New York, 1974, Chapter 9.

[13] L. Rebouta, C.J. Tavares, R. Aimo, et al., Surf. Coat. Technol. 133-134 (2000) 234

[14] R. Hauert, J. Patscheider, Adv. Eng. Mater. 2 (5) (2000) 247.

[15] W.-D. Münz, J. Vac. Sci. Tecnol. A 4 (6) (1986) 2717.

[16] O. Knotek, M. Böhmer, T. Leyendecker, J. Vac. Sci. Technol. A 4 (6) (1986) 2695.

[17] A. Niederhofer, P. Nesládek, H.D. Männling, S. Veprek, M. Jílek, Surf. Coat. Technol. 120-121 (1999) 173. 
[18] F. Vaz, L. Rebouta, Ph. Goudeau, T. Girardeau, J. Pacaud, J.P. Rivière, A. Traverse, Surf. Coat. Technol. 146-147 (2001) 274.

[19] S. Carvalho, E. Ribeiro, L. Rebouta, et al., Surf. Coat. Technol., in press.

[20] C. Friedrich, G. Berg, E. Broszeit, C. Berger, Mat.-wiss.u. Werkstoffech. 28 (1997) 59.

[21] R. Hertzberg, Deformation and Fracture Mechanics of Engineering Materials, third ed., Wiley, New York, 1989.

[22] A. Kelly, N.H. MacMillan, Strong Materials, third ed., Clarendon, Oxford, 1986.

[23] C. Louro, A. Cavaleiro, Surf. Coat. Technol. 116-119 (1999) 74.

[24] B.D. Cullity, Elements of X-ray Diffraction, second ed., Addison-Wesley, Menlo Park, CA, 1978, p. 103.

[25] N.J.M. Carvalho, J.Th.M. DeHosson, Thin Solid Films 388 (2001) 150-159.

[26] F. Vaz, L. Rebouta, B. Almeida, et al., Surf. Coat. Technol. 120-121 (1999) 166.

[27] S. Carvalho, L. Rebouta, A. Cavaleiro, L.A. Rocha, J. Gomes, E. Alves, Thin solid Films 398-399 (2001) 391.

[28] M. Diserens, J. Patscheider, F. Lévy, Surf. Coat. Technol. 108109 (1998) 241.

[29] B.A. Movchan, A.V. Demchishin, Fizita Metall. 28 (1969).

[30] J.A. Thornton, Ann. Rev. Mater. Sci. 7 (1977) 239.

[31] J. Musil, J. Vlček, Surf. Coat. Technol. 142-144 (2001) 557.

[32] P. Barna, M. Adamik, Formation and characterization of the structure of surface coatings, in: Y. Paleau, P.B. Barna (Eds.), Protective Coatings and Thin Solid Films, Kluwer Academic Publisher, 1997.
[33] M.A. Adamik, P.B. Barna, I. Tomov, Thin Solid Films 317 (1998) 64.

[34] S. Carvalho, F. Vaz, L. Rebouta, D. Schneider, A. Cavaleiro, E. Alves, Surf. Coat. Technol. 142-144 (2001) 110.

[35] W. Kreher, W. Pompe, Internal Stresses in Heterogeneous Solids, Physical Research, vol. 9, Academic-Verlag, Berlin, 1989.

[36] D.P.H. Hasselman, J. Am. Ceram. Soc. 45 (1962) 452.

[37] G. Ondracek, Proceeding of Colloquium Brussels, 1988.

[38] M. Kupkova, J. Mater. Sci. 28 (1993) 5265.

[39] K.K. Phani, J. Mater. Sci. 31 (1996) 272.

[40] D. Schneider, Th. Schwarz, H.-P. Buchkremer, D. Stöver, Thin Solid Films 224 (1993) 177.

[41] C. Kral, W. Lengauer, D. Rafaja, P. Ettmayer, J. Alloys Compd. 265 (1998) 215.

[42] L.E. Toth, Transition Metal Carbides and Nitrides, Academic, New York, 1971.

[43] S.T. Oyama, Introduction to the chemistry of transition metal carbides and nitrides, in: S.T. Oyama (Ed.), Transition Metal Carbides and Nitrides: Application of Transition Metal Carbides and Nitrides in Industrial Tools, Blackie, Acad and Prof, London, 1996, Chapter 1, p. 1.

[44] A.T. Santhanam, Introduction to the chemistry of transition metal carbides and nitrides, in: S.T. Oyama (Ed.), Transition Metal Carbides and Nitrides: Application of Transition Metal Carbides and Nitrides in Industrial Tools, Blackie, Acad and Prof, London, 1996, Chapter 2, p. 28.

[45] A.J. Perry, Thin Solid Films 193 (1-2) (1990) 463.

[46] H.J. Kim, Y.G. Kweon, Thin Solid Films 342 (1999) 201.

[47] D. Schneider, B. Schultrich, H.-J. Scheibe, H. Ziegele, M. Griepentrog, Thin Solid Films 332 (1998) 157-163. 